Vol: 2, Issue: 6

June/2021

https://ijbssrnet.com/index.php/ijbssr

DOI: http://dx.doi.org/10.47742/ijbssr.v2n6p2

\title{
The Influence of Liquidity, Leverage, Company Size and Profitability on Financial Distress
}

\section{Dedy Samsul Arifin ${ }^{1}$, Arifuddin Masud ${ }^{2}$, Ummy Kalsum $^{3}$, Andi Runis Makkulau ${ }^{4}$}

${ }^{1}$ Magister of Management Program High School of Economic Science of Enam Enam Kendari, Indonesian

${ }^{2}$ Faculty of Economics and Business, Halu Oleo University, Indonesian

${ }^{3}$ Magister of Management Program High School of Economic Science of Enam Enam Kendari, Indonesian

${ }^{4}$ Magister of Management Program High School of Economic Science of Enam Enam Kendari, Indonesian

\section{A R T I C L E I N F O \\ Article history: Article \\ Received: $\quad 07$ June 2021 \\ Revised: $\quad 15$ June 2021 \\ Accepted: $\quad 25$ June 2021 \\ DOI: $10.47742 /$ ijbssr.v2n6p2}

\begin{abstract}
A B S T R A C T
This study aims to empirically examine the factors that influence Financial Distress in Property and Real Estate Companies. This study was tested with four independent variables, namely Liquidity (Current Ratio), Leverage (Debt Equity Ratio), Firm Size (In of Total Assets), and Profitability (Return on Assets) using purposive sampling technique the authors chose seventeen companies as samples. This study uses panel data analysis obtained from financial reports and Annual Reports for 5 years. This study uses secondary data with the help of the Eviews 9 application. The results found that the Leverage Variable (Debt Equity Ratio) has a positive and significant influence on Financial Distress while Liquidity (Current Ratio), Company Size (In of Total Assets), and Profitability Variables (Return). on Assets) has a negative and significant effect on Financial Distress. Keywords: Financial Distress, Liquidity, Leverage, Company Size, and Profitability
\end{abstract}

\section{Introduction}

In the current era of globalization, companies are required to be more competitive by showing various advantages to dominate the world market because free trade makes companies not only compete in the domestic sphere but also compete with foreign companies(Wahyuningsih and Suryanawa, 2012). The growth rate of world economic conditions is progressing quite rapidly every year, various ways are carried out by business actors to maintain and develop competitive advantages with their competitors (Horne, JC and Wachowicz, 2007).

The company is an organization that was founded to make big profits. In addition, the company also focuses on the survival of the company so that it can continue to run. The going concern assumption is used by a business entity in running its business. With a going concern, an entity is considered capable of maintaining its business in the long term and will not be liquidated in the short term (Prabowo \& Wibowo, 2017). The ability of management in a company to keep the company running will prevent the company from financial distress which can lead to business bankruptcy in the future.

The company is said to be experiencing a condition of financial distress (financial distress) if the company cannot meet the schedule for repaying its debts to creditors at maturity. The company's inability to be able to meet its financial obligations continuously can make the company experienced bankruptcy or financial distress.
Financial distress by the company can be measured using financial statements issued by the company, the company's financial statements are a source of information about the financial conditions that occur in the company, performance, and changes in the company's financial position which are very useful to support in making the right decisions The financial distress model needs to be developed because by knowing the condition of the company's financial difficulties early on, it is hoped that actions can be taken to prevent or anticipate which leads to the company's bankruptcy.

Property business currently provides opportunities and opportunities that are open to development. The opening of these opportunities, of course, is an opportunity to invite foreign and domestic investors to be able to invest domestically, so that funds will flow to Indonesia through foreign investment and can provide profits to help the growth of the Real Estate business in Indonesia.

The property industry in the country is observed to be still sluggish. From 2016 to 2018 purchases in the property sector have decreased. This condition is reflected in the decline in sales growth and advances as well as the low sales value in 2018. Bank Indonesia recorded total sales in 2018 only reaching $\mathrm{Rp} 27.68$ trillion. Down from the position in 2017 which reached $\mathrm{Rp} 42$ trillion. The 2018 record was also lower than the 2016 position which amounted to Rp 34.51 trillion. The following is a table that shows the total assets, profits, and debts of Property and Real Estate companies from 2015-2019. 


\section{Comparison of Assets, Liabilities, Sales and Profits in Real Estate Companies on the Indonesia Stock Exchange 2015-2019}

\begin{tabular}{|c|c|c|c|c|}
\hline \multirow{2}{*}{ Year } & \multicolumn{4}{|c|}{ Account } \\
\cline { 2 - 5 } & Assets (Rp) & Debt (Rp) & Sales (Rp) & Profit (Rp) \\
\hline 2015 & 129.910 .789 .533 & 53.977 .446 .404 & 16.210 .192 .877 & 8.249 .311 .120 \\
\hline 2016 & 112.436 .185 .916 & 43.293 .268 .541 & 15.477 .303 .405 & 6.713 .649 .791 \\
\hline 2017 & 127.644 .951 .996 & 47.465 .651 .738 & 16.515 .748 .260 & 9.371 .107 .645 \\
\hline 2018 & 138.548 .330 .719 & 56.800 .533 .007 & 16.089 .271 .037 & 7.761 .016 .233 \\
\hline 2019 & 141.140 .679 .902 & 56.366 .893 .126 & 15.424 .024 .987 & 5.389 .062 .254 \\
\hline
\end{tabular}

Source: Data Processed, 2021

Based on table 1.1 the comparison of total assets, liabilities, sales, and profits above, it can be seen that the company's assets in 2015 amounted to Rp. 129,910,789,533, the company's debt was Rp. 53,977,446,404 with sales of Rp. $16,210,192,877$ and the company's profit of Rp. 8,249,311,120. In 2016 the company's assets decreased by Rp 112,436,185,916, the company's debt decreased by Rp 43,293,268,541 with sales decreased by Rp 15,477,303,405 and the company's profit decreased by Rp 6,713,649,791. In 2017 the company's assets increased by Rp. 127,644,951,996, the company's debt increased by Rp. 47,465,651,738 with sales and an increase of Rp. 16,515,748,260 and the company's profit increased by Rp. 9,371,107,645. In 2018 the company's assets increased by Rp. 138,548,330,719, the company's debt increased by Rp. 56,100,533,007 with sales decreased by Rp. 16,089,271,037 and the company's profit decreased by Rp. 7,761,016,233. While in 2019 the company's assets increased by Rp. 141,140,679,902, the company's debt increased by Rp. 56,366,893,126 with sales decreased by Rp. $15,424,024,987$ and the company's profit decreased by Rp. $5,389,062,254$.

Based on the description of the comparison of assets, debt, sales, and profits from 2015-2019, it can be seen that the profits obtained by the company fluctuated due to the use of debt which continues to grow from year to year even though the company's assets have increased from year to year. From this comparison, we can also see that in 2016, assets, debts, and profits of property and real estate companies decreased.
Research conducted by Rahmadona Amelia Ftiri and Syamwil (2019) shows that profitability and leverage have a significant negative effect on financial distress and liquidity has a significant positive effect on financial distress. Another thing that the research conducted by Chintya Christella and Marian Stefani Osesago (2019) showed that profitability and liquidity had a significant positive effect on financial distress and leverage had a significant negative effect on financial distress. Meanwhile, research conducted by Dian Primiati Oktasari (2020) shows that company size has a significant positive effect on financial distress. Another thing that research conducted by Angela Dirman (2020) shows that company size has a significant negative effect on financial distress.

\section{Conceptual Framework and Hypotheses}

Based on theoretical studies and the results of previous studies, the researchers developed a conceptual framework that will examine several variables, namely liquidity (X1), leverage (X2), company size (X3), profitability (X4), and financial distress variable (Y). This study will analyze the effect of liquidity, leverage, company size, and profitability on financial distress in Property and Real Estate companies listed on the Indonesian stock exchange in 2015-2019. The conceptual framework in this study was built based on the formulation of the problem, research objectives, theoretical studies, and the results of previous studies as the basis for formulating hypotheses.

Based on the explanation above, the conceptual framework in this study is presented in the following scheme.

\section{Conceptual framework}

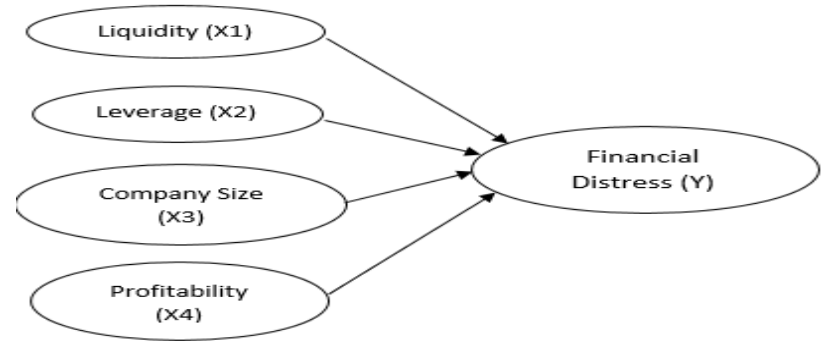

\section{Hypothesis}

Based on the problem formulation, research objectives, theoretical studies, and empirical studies, the research hypotheses are as follows:
1. Liquidity, leverage, firm size, and profitability have a positive and significant effect on financial distress in real estate companies.

2. Liquidity has a negative and significant effect on financial distress in real estate companies. 
Vol: 2, Issue: 6

June/2021

https://ijbssrnet.com/index.php/ijbssr

DOI: $\underline{\text { http://dx.doi.org/10.47742/ijbssr.v2n6p2 }}$

http://iarpnet.org/

3. Leverage has a positive and significant effect on financial distress in real estate companies.

4. Company size has a negative and significant effect on financial distress.

5. Profitability has a negative and significant effect on financial distress in Real Estate companies.

Research Method

\section{Research Object}

The objects in this study are liquidity, leverage, firm size, and profitability as independent variables and financial distress as the dependent variable in Real Estate companies listed on the Indonesia Stock Exchange in 2015-2019.

\section{Population}

In this study, the population taken is companies engaged in the real estate sector and listed as public (issuers) listed on the Indonesia Stock Exchange (IDX) in 2015-2019. The number of
Real Estate companies that went public until 2019 amounted to 62 companies.

\section{Sample}

Sampling in this study using purposive sampling. Sugiyono (2012:126) explains that purposive sampling is a sampling technique with certain considerations. The purpose of this method is to obtain a sample for certain considerations with predetermined criteria to get a representative sample. The criteria used to select the sample in this study are as follows:

1. Real estate companies are listed on the Indonesia Stock Exchange until 2019.

2. The company publishes an annual report on the Indonesia Stock Exchange consecutively during the year of observation in 2015-2019.

3. Real estate companies that experienced positive profit growth from 2015-2019

Table 4.1

Research Sample Criteria

\begin{tabular}{|c|l|c|}
\hline No. & \multicolumn{1}{|c|}{ Criteria } & Amount \\
\hline 1. & Real estate companies listed on the Indonesia Stock Exchange (IDX) in 2019 & 62 \\
\hline 2. & Real estate company that publishes annual financial reports (Annual Report) from 2015-2019 & $(32)$ \\
\hline 3. & Real estate companies that experienced positive profit growth from 2015-2019 & $(15)$ \\
\hline & & Number of Samples \\
\hline
\end{tabular}

Source: www.idx.co.id

Data Types and Data Sources

Data Type

The type of data used in this research is quantitative data. According to Silalahi (2010: 282), quantitative data is data from a series of observations or measurements expressed in numbers. Quantitative data based on time classification can be categorized as time-series data, cross-section, and panel data. In this study, the data used is panel data, which is a combination of time series data and cross-section data.

\section{Data source}

There are two sources of data, namely primary data and secondary data. In this study, the data source used is secondary data. Secondary data is data collected from second-hand or from other sources that were available before the research was conducted (Silalahi, 2010:291). The source of data used in this study is the published financial statements of companies listed on the Indonesia Stock Exchange (IDX) in 2015-2019.

\section{Data analysis method}

The data analysis technique used in this study is panel data regression with the help of the Eviews 9 program. Panel data regression is a regression technique that combines time series data with cross-section. Widarjono (2013) said that the panel data regression method has several advantages when compared to time series or cross-section data. First, panel data which is a combination of two-time series and cross-section data can provide more data so that it will produce a greater degree of freedom.

\section{Panel Data Regression Analysis}

Multiple regression analysis in this study aims to test and explain the effect of each research variable (Ghozali, 2011). Multiple regression analysis in this study was conducted to determine the effect of the independent variables liquidity, leverage, firm size, and profitability both simultaneously and partially on financial distress. The panel data regression equation model in this study is as follows:

$Y=\beta_{0}+b_{1} X_{1 i-t}-b_{2} X_{2 i-t}+b_{3} X_{3 i-t}+b_{4} X_{4 i-t}+e_{\text {i-t }}$ Information:

Y = Financial Distress (FIN_DIS)

$\beta_{0}=$ constant

b1-b4 = regression coefficient

$\mathrm{X} 1=$ Profitability $(\mathrm{ROA})$ in unit $\mathrm{i}$ in period $\mathrm{t}$

$\mathrm{X} 2=$ Liquidity $(\mathrm{CR})$ in unit $\mathrm{i}$ in period $\mathrm{t}$

$\mathrm{X} 3=$ Leverage (DER) on unit $\mathrm{i}$ in period $\mathrm{t}$

$\mathrm{X} 4=$ Firm Size (UP) in unit $\mathrm{i}$ in period $\mathrm{t}$

$\mathrm{e} \quad=$ error term in unit $\mathrm{i}$ in period $\mathrm{t}$

Determination of the Estimation Model

\section{Common effects models}

This technique is the simplest technique for estimating the parameters of the panel data model, namely by combining cross-section and time-series data as a single unit without looking at differences in time and entities (individuals). Where the approach that is often used is the ordinary least square. The Common Effect model ignores the differences in individual and 
Vol: 2, Issue: 6

June/2021

https://ijbssrnet.com/index.php/ijbssr DOI: $\underline{\text { http://dx.doi.org/10.47742/ijbssr.v2n6p2 }}$

time dimensions or in other words the behavior of the data between individuals is the same in various periods.

\section{Fixed effect model}

The fixed-effect model approach assumes that the intercept of each individual is different while the slope between individuals is the same (the same). This technique uses a dummy variable to capture the differences in intercepts between individuals.

\section{Random effect model}

If in the Fixed Effects Model, differences between individuals and/or time are reflected through intercepts, then in the Random Effects Model, these differences are accommodated

Table 5.12 Chow Test Results

through errors. This technique also takes into account that errors may be correlated across time series and cross-sections.

\section{Results and Discussion}

\section{Chow test}

The Chow test was conducted to determine whether the common effect model or the fixed effect model was more appropriate to use in the panel data regression equation model. To compare the common effect model with the fixed-effect model, a statistical $F$ test was performed. The F test is used to compare the common effects model which assumes that the intercept model for all cross-section units is the same as the fixed-effect model which assumes that it is different from the cross-section.

\begin{tabular}{|llll|}
\hline $\begin{array}{l}\text { Redundant Fixed Effects Tests } \\
\text { Equation: Untitled } \\
\text { Test cross-section fixed effects }\end{array}$ & & & \\
\hline \hline Effects Test & Statistic & d.f. & Prob. \\
\hline \hline Cross-section F & 41.653867 & $(16,64)$ & 0.0000 \\
Cross-section Chi-square & 206.957485 & 16 & 0.0000 \\
\hline \hline
\end{tabular}

Source: Eviews 9 Results, 2021

Based on table 5.12, it can be seen that the probability value (Prob) for the Chi-square cross-section is 0.0000 which is $<0.05$. So it can be concluded that the fixed-effect model is more appropriate to use than the common effect model. Because of the selected fixed-effect model, there is no need to perform the Lagrangian Multiplier Test.

Table 5.13 Hausman's test

\begin{tabular}{|lll|}
\hline $\begin{array}{l}\text { Correlated Random Effects - Hausman Test } \\
\text { Equation: Untitled } \\
\text { Test cross-section random effects }\end{array}$ \\
\hline \hline & $\begin{array}{l}\text { Chi-Sq. } \\
\text { Statistic }\end{array}$ & Chi-Sq. d.f. Prob. \\
\hline Test Summary & 3.519082 & 4 \\
\hline \hline Cross-section random & & 0.4750 \\
\hline \hline
\end{tabular}

Source: Eviews 9 Results, 2021

Based on table 5.13, it can be seen that the probability Based on the selection of the estimation model above, the value (Prob) of a random cross-section is 0.4750 which the value is $>0.05$. So it can be concluded that the random effect model is more appropriate to use than the fixed effect model.

\section{Panel Data Regression Analysis}

\section{Hausman test}

Hausman test is conducted to compare or choose which model is the best between the Fixed Effect model and the

Random Effect model. 
Vol: 2, Issue: 6

June/2021

https://ijbssrnet.com/index.php/ijbssr

DOI: http://dx.doi.org/10.47742/ijbssr.v2n6p2

Based on the table above, the regression equation formed in this study is as follows:

Financial Distress $=5.9027-0.6570 \mathrm{X} 1+9.6598 \mathrm{X} 2-$ 0.1157 X3-8.9393 X4

\section{Hypothesis Test Results}

This study uses multiple regression analysis in data processing. This analysis uses the simultaneous test (F-test),

Table 5.15 Simultaneous Tést Results Variables

\begin{tabular}{|llll|}
\hline \hline R-squared & 0.551761 & Mean dependent var & 0.643694 \\
Adjusted R-squared & 0.529349 & S.D. dependent var & 1.280966 \\
S.E. of regression & 0.878795 & Sum squared resid & 61.78240 \\
F-statistic & 24.61901 & Durbin-Watson stat & 1.009265 \\
Prob(F-statistic) & 0.000000 & & \\
\hline \hline
\end{tabular}

Source: Eviews 9 Results, 2021

Based on table 5.15, it can be seen that the profitability value of the F-statistic for the random effect model is $\mathrm{F}=0.00<$ 0.05 . With a feasibility level of 5\% (alpha 0.05), it accepts $\mathrm{H} 1$ or which means that liquidity, leverage, company size, and profitability simultaneously or together have a significant influence on the financial distress of Real Estate Companies listed on the Indonesia Stock Exchange.

\section{Partial Test (t-Test)}

T statistical test to measure how far the influence of each independent variable in explaining the dependent variable with a significance level of $5 \%$ or 0.05 .

Table 5.16 Variable Partial Test Results

\begin{tabular}{|crrrr|}
\hline \hline Variable & Coefficient & Std. Error & t-Statistic & Prob. \\
\hline \hline C & 5.902745 & 2.111823 & 2.795095 & 0.0065 \\
CR & -0.657066 & 0.089129 & 7.372069 & 0.0000 \\
DER & 9.659863 & 2.506187 & -3.854407 & 0.0002 \\
SIZE & -0.115769 & 0.135205 & 0.856249 & 0.0344 \\
ROA & -8.939376 & 4.560298 & -1.960261 & 0.0504 \\
\hline \hline
\end{tabular}

Source: Eviews 9 Results, 2021

Based on table 5.16 it can be concluded that:

1. Based on table 5.15, it can be seen that the profitability value of the F-statistic for the random effect model is $\mathrm{F}$ $=0.00<0.05$. With a feasibility level of $5 \%$ (alpha 0.05 ), it accepts $\mathrm{H} 1$ or which means that liquidity, leverage, company size, and profitability simultaneously or together have a significant influence on the financial distress of Real Estate Companies listed on the Indonesia Stock Exchange.

2. The liquidity variable (X1) has a negative and significant effect on financial distress. This is indicated by the coefficient current ratio (CR) of -0.657066 which is negative and the significance value is $0.0065<0.05$, it can be concluded that the liquidity variable (X1) at a significance level of 0.05 partially has a significant effect on financial distress.

3. The leverage variable (X2) has a positive and significant effect on financial distress. This is indicated by the value of the coefficient debt to equity ratio (DER) of 9.659863 which is positive and a significance value of 0.0002
$<0.05$, it can be concluded that the leverage variable (X2) at a significance level of 0.05 partially has a significant effect on financial distress.

4. The firm size variable (X3) has a negative and significant effect on financial distress. This is indicated by the value of the firm size coefficient (size) of -0.115769 which is negative and the significance value is $0.0344<0.05$, it can be concluded that the firm size variable (X3) at a significance level of 0.05 partially has a significant effect on financial distress.

5. The profitability variable (X4) has a negative and significant effect on financial distress. This is indicated by the coefficient of return on assets (ROA) of -8.939376 which is negative and a significance value of 0.0504 $<0.05$, it can be concluded that the profitability variable (X4) at a significance level of 0.05 partially has a significant influence on financial distress.

Coefficient of determination test $\left(R^{2}\right)$

The coefficient of determination $\left(\mathrm{R}^{2}\right)$ test is used to measure how far the model's ability to explain the variation of the 
Vol: 2, Issue: 6

June/2021

https://ijbssrnet.com/index.php/ijbssr

DOI: $\underline{\text { http://dx.doi.org/10.47742/ijbssr.v2n6p2 }}$

dependent variable is. The value of the coefficient of dependent variable. This study uses the coefficient of determination is between 0 and 1 . If the value of the coefficient determination by using the R-square value to evaluate the of determination is close to one, then the independent variable regression model. The R-squared value in the study can be seen provides almost all the information needed to predict the in Table 5.17 below:

Table 5.17 Results of the Coefficient of Determination

\begin{tabular}{|llll|}
\hline \hline R-squared & 0.551761 & Mean dependent var & 0.643694 \\
Adjusted R-squared & 0.529349 & S.D. dependent var & 1.280966 \\
S.E. of regression & 0.878795 & Sum squared resid & 61.78240 \\
F-statistic & 24.61901 & Durbin-Watson stat & 1.009265 \\
Prob(F-statistic) & 0.000000 & & \\
\hline \hline
\end{tabular}

Source: Eviews 9 Results, 2021

The magnitude of the relationship between liquidity, leverage, company size, and profitability on the Financial Distress of Real Estate companies listed on the Indonesia Stock Exchange in 2015-2019 can be shown by the coefficient of determination. Based on table 5.17, the test results using the random effect model on Real Estate companies listed on the IDX obtained an R-squared $\left(\mathrm{R}^{2}\right)$ of 0.551761 or $55 \%$, meaning that the variables of liquidity, leverage, company size, and profitability can explain the financial distress variable. by $55 \%$. While the remaining $45 \%(100 \%-55 \%)$ the rest is explained by other variables outside the model. By paying attention to the size of the R-Square of $55 \%$, which means that the level of relationship between the variables of liquidity, leverage, company size, and profitability on Financial Distress is quite strong.

\section{Discussion}

\section{Effect of Liquidity, Leverage, Firm Size and Profitability on Financial Distress}

Liquidity, leverage, company size, and profitability on financial distress in Real Estate Companies can be seen in the RSquare determination value of 0.55 . This means that the contribution of the independent variables of liquidity, leverage, firm size, and profitability to financial distress is $55 \%$ while the remaining $45 \%$ is the influence of other variables not included in this study.

The existence of a significant influence in this study implies that liquidity, leverage, company size, and profitability which are the company's financial performance can be used by potential investors as material to be considered in assessing the financial distress of the company that will be chosen to invest. With good financial performance, the company will attract the attention of investors to invest so that the company does not experience financial distress. The results of this study are relevant to the research of Maulana Arba Aryadi (2018), which found that liquidity, leverage, firm size, and profitability together have a significant effect on financial distress.

\section{Effect of Liquidity on Financial Distress}

Based on the results of the regression analysis that has been carried out, the regression coefficient value is -0.657066 , the $t$-count value is 7.37 , and the significant probability is 0.0000 which is smaller than the significant level set $=0.05$. The relationship between liquidity and financial distress can be seen in the regression coefficient, which is -0.657066 , which means that there is a negative relationship between liquidity and financial distress.

According to economic theory, the higher the company's liquidity, the more the company will avoid financial distress, meaning that the relationship between liquidity and financial distress has a negative effect. The liquidity ratio is the company's ability to generate cash in the short term to meet obligations and the reason for the widespread use of current assets (Subramanyamdan, 2011).

The results of this study support the research conducted by Angela Dirman (2020), showing that liquidity has a negative and significant effect on financial distress. So that hypothesis 1 which states that liquidity has a negative and significant effect on financial distress is accepted.

\section{Effect of Leverage on Financial Distress}

Based on the results of the regression analysis that has been carried out, the regression coefficient value is 9.659863, the t-count value is -3.85 , and the significant probability is 0.0002 which is smaller than the significant level set $=0.05$. The relationship between liquidity and financial distress can be seen in the regression coefficient, which is 9.659863 , which means that there is a positive relationship between leverage and financial distress.

The results of this study support the research conducted by Dian Primanita Oktasari (2020) and Mochamad Rifky Irwandi and Sri Rahayu (2019) showing that leverage has a positive effect on financial distress. So that hypothesis 2 which states that leverage has a positive and significant effect on financial distress is accepted.

\section{Effect of Firm Size on Financial Distress}

Based on the results of the regression analysis that has been carried out, the regression coefficient value is -0.115769 , the t-count value is 0.85 , and the significant probability is 0.0344 which is smaller than the significant level set $=0.05$. The relationship between company size and financial distress can be seen in the regression coefficient, which is -0.115769 , which means that there is a negative relationship between company size and financial distress.

The results of this study support the research conducted by Andrew Jaya Saputra \& Susanto Salim (2020) showing that company size has a negative and significant effect on financial 
Vol: 2, Issue: 6

June/2021

https://ijbssrnet.com/index.php/ijbssr

DOI: http://dx.doi.org/10.47742/ijbssr.v2n6p2

distress. So that hypothesis 3 which states that company size has predicting financial distress, the following conclusions can be a negative and significant effect on financial distress is accepted. drawn:

\section{Effect of Profitability on Financial Distress}

Based on the results of the regression analysis that has been carried out, the regression coefficient value is -8.939376 , the t-count is -1.96 , and the significant probability is 0.05 which is smaller than the significant level set $=0.05$. The relationship between profitability and financial distress can be seen in the regression coefficient, which is -8.939376 , which means that there is a negative relationship between profitability and financial distress.

The results of this study support the research conducted by Andrew Jaya Saputra \& Susanto Salim (2020) and Angela Dirman (2020) which shows that profitability has a negative and significant effect on financial distress. So that hypothesis 4 which states that profitability has a negative and significant effect on financial distress is accepted.

\section{Conclusions}

Based on the results of research and discussion on the effect of liquidity, leverage, firm size, and profitability in
1. The ratio of liquidity, leverage, company size, and profitability together have a positive and significant effect in predicting financial distress in real estate companies listed on the IDX for the 2015-2019 period.

2. The liquidity ratio has a negative and significant effect in predicting financial distress in real estate companies listed on the IDX for the 2015-2019 period.

3. The leverage ratio has a positive and significant effect in predicting financial distress in real estate companies listed on the IDX for the 2015-2019 period.

4. The company size ratio has a negative and significant effect in predicting financial distress in real estate companies listed on the IDX for the 2015-2019 period.

5. The profitability ratio has a negative and significant effect in predicting financial distress in real estate companies listed on the IDX for the 2015-2019 period.

\section{References}

Andrew Jaya Saputra \& Susanto Salim (2020) berjudul "Pengaruh Profitabilitas, Leverage, Firm Size dan Sales Growth Terhadap Financial Distress".

Angela Dirman. (2020). "Financial Distress : The Impacts of Profitability, Likuidity, Leverage, Firm Size and Free Cash Flow".

Aryadi, Maulana Arba (2018) Pengaruh profitabilitas, likuiditas, leverage, dan ukuran perusahaan terhadap Financial distress. Undergraduate thesis, STIE PERBANAS SURABAYA.Chintya Christella dan Marian Sefani Osesago. (2019).

"Pengaruh Leverage, Profitabilitas, Kepemilikan Institusional, Likuiditas dan Ukuran Perusahaan Terhadap Financial Distress (Studi Pada Perusahaan Manufaktur di BEI tahun 2014-2016)".

Dian Primanita Oktasari. (2020). The Effect of Liquidity, Leverage, and Firm Size on Financial Distress. Jilid 3. Edisi 9. Sep 2020. Kenya.

Ghozali, Imam. 2011. Aplikasi Analisis Multivariate dengan Program SPSS.Semarang: Badan Penerbit Universitas Diponegoro.

Horne, J.C. dan Wachowicz, J. M. (2014). Prinsip-Prinsip Manajemen Keuangan. In Prinsip Prinsip Manajemen Keuangan. https://doi.org/10.4324/9781315641348.

Mochamad Rifky Irwandi dan Sri Rahayu. (2019). "Pengaruh Inflasi, Likuiditas dan Leverage Terhadap Financial Distress”. Vol 6, No 3 Desember 2019.

Prabowo, A., \& Wibowo, A. (2017). Pengaruh Persepsi Harga, Persepsi Kualitas Produk, dan Citra Merek terhadap Keputusan Pembelian Sepeda Motor Yamaha Vixion (Studi: Pengguna Sepeda Motor Yamaha Vixion Dicondongcatur). STIE Widya Wiwaha.

Rahmadona Amelia Fitri dan Syamwil. (2019). "Pengaruh Likuiditas, Aktivitas, Profitabilitas dan Leverage Terhadap Financial Distress (Studi Kasus pada Perusahaan Manufaktur yang Terdaftar di Bursa Efek Indonesia Periode 2014-2018)”. Vol 3 No 1, Hal 134-143.

Silalahi, Ulber. 2010. Metode Penelitian Sosial. Bandung:PTRefika Aditama.

Wahyuningsih, Nur, dan Suryanawa. 2012. Analisis Pengarus Opini Audit Going Concern dan Pergantian Manajemen pada Auditor Switching. Jurnal Ilmiah Akuntansi dan Bisnis.Vol: 7. No: 1. Hal: 1-20.

Widarjono, Agus. 2013. Ekonometrika: Pengantar dan aplikasinya. Ekonosia, Jakarta. 